\title{
Skeletochronology, age at maturity and cause of mortality of loggerhead sea turtles Caretta caretta stranded along the beaches of Campania (south-western Italy, western Mediterranean Sea)
}

Fabio Maria Guarinoํ, Fabio Di Nocera ${ }^{2}$, Francesco Pollaro ${ }^{3}$, Giorgio Galiero², Doriana Iaccarino², Domenico Iovino ${ }^{1}$, Marcello Mezzasalma ${ }^{1,4}$, Agnese Petraccioli ${ }^{1}$, Gaetano Odierna ${ }^{1}$, Nicola Maio $^{1}$

1 Dipartimento di Biologia, Università degli Studi di Napoli Federico II, Napoli, Italy

2 Istituto Zooprofilattico Sperimentale del Mezzogiorno, Dipartimento di Sanità Animale, Portici (Naples), Italy

3 Associazione Centro Studi Ecosistemi Mediterranei Pioppi (Pollica, Salerno), Italy

4 Department of Life Sciences, Natural History Museum, Cromwell Road, London, UK

http://zoobank.org/7C408B1A-9049-4783-8461-D7978F57AEAF

Corresponding author: Fabio Maria Guarino (fabio.guarino@unina.it), Marcello Mezzasalma (m.mezzasalma@gmail.com)

Academic editor: Yurii Kornilev • Received 23 October 2019 • Accepted 10 March 2020 • Published 15 April 2020

\begin{abstract}
Information on demographic and life-history traits of endangered vertebrate species, such as sea turtles, is crucial for planning management and conservation actions. We applied skeletochronology of phalanges to estimate the age of loggerhead turtles, Caretta caretta, found dead stranded along the beaches of Campania (western Mediterranean) from 2013 to 2017. To obtain maturity data, we examined gonads from a subsample of 7 males and 11 females. Overall, curved carapace length (CCL) ranged from 5.6 to $90.8 \mathrm{~cm}$, but for most turtles (89\%) it was 50-79.9 cm. Predominance of stranded females (62\%) was recorded. Ten out of the eighteen histologically examined gonads allowed estimating maturity. Based on the lines of arrested growth counting, the estimated age of the examined specimens ranged from 0 (hatchling) to 26 years. The modal age was 14 years for males and 17 years for females. The smallest male with spermatogenetic activity had a CCL of $65 \mathrm{~cm}$ and was estimated to be 16 years old. The smallest female with follicular development stage, characterising the transition towards adulthood, had a CCL of $69.5 \mathrm{~cm}$ and was estimated to be 20 years old. Anthropogenic factors were responsible for $36 \%$ of the mortality of individuals, followed by parasitic/infective pathologies (20\%).
\end{abstract}

\section{Key Words}

age structure, Caretta caretta, cause of death, gonadal analysis, marine turtles, Mediterranean Sea, phalanx, sexual maturity

\section{Introduction}

Accurate information on the age at sexual maturity and longevity of individuals is crucial for understanding the structure of a population in its natural environment and implementing appropriate strategies for the management and conservation of threatened species (Avens et al. 2017). This is especially important for species that are still understudied or can be considered model or- ganisms in different fields of biology (Blackburn 2006; Camargo et al. 2010; Mezzasalma et al. 2016, 2017a, b; de Miranda 2017).

The loggerhead sea turtle, Caretta caretta (Linnaeus, 1758), is circumglobally distributed throughout subtropical and temperate regions, including the Mediterranean Sea, in the Pacific, Atlantic and Indian oceans (Wallace et al. 2010); it is the most abundant sea turtle in Italian waters (Giacoma et al. 2007). 
In the IUCN Red List of Threatened Species (ver. 2019-1), C. caretta is globally listed as Vulnerable (Casale and Tucker 2017); it is endangered in Italy (Rondinini et al. 2013). Among the most probable causes of the decreasing trend of the Mediterranean populations of this species are the degradation of coastal and open sea habitats, the prolonged illegal trade, and fishery bycatch (Lutcavage et al. 1997; Margaritoulis et al. 2003; Casale et al. 2004; Mingozzi et al. 2007).

Caretta caretta is frequently found dead stranded on the beaches or coastal waters of Italy, including those of Campania (southwestern Italy, Tyrrhenian Sea, western Mediterranean). During 1980-2008, 5938 individuals were recorded along Italian coasts as stranded (2375, of which $77 \%$ were dead) or floating (1494, of which approximately $13 \%$ were dead) individuals, while the state of the remaining 2069 individuals was not specified (Casale et al. 2010).

Between 2012 and 2018, 130 dead or dying individuals of $C$. caretta were found stranded on Campanian beaches (Istituto Zooprofilattico Sperimentale del Mezzogiorno, Napoli, Italy, unpublished data). However, this number is likely underestimated, since other organisations locally involved in the monitoring of this species do not always freely share their data.

Between 1-6 nests have been recorded yearly since 2010 (except 0 nests in 2011; Suppl. material 1: Table $\mathrm{S} 1$ ), even when Campanian beaches have been highly degraded (Mingozzi et al. 2007).

There are several techniques for determining the age of marine turtles, each with some difficulties in application and interpretation. The earliest estimates of age-atsize and age at first reproduction for wild sea turtles were provided using growth data from mark-recapture studies. This remains one of the most common approaches for estimating somatic growth rates, age at sexual maturation, and stage duration in sea turtles (Avens and Snover 2013).

Skeletochronology is one of the most reliable indirect methods for estimating the age and growth rates of marine turtles (for a review see Avens and Snover 2013; Goshe et al. 2016; Avens et al. 2017) and other vertebrates, particularly amphibians (see Guarino et al. 2011, 2014; Sinsch 2015) and reptiles (see Castanet 1994; Guarino et al. 2015). It is a histological method based on the interpretation of the incremental growth marks that are formed in the mineralised tissues of an individual throughout its life cycle, corresponding with the deceleration or stopping of the somatic growth (Castanet and Smirina 1990; Castanet et al. 1993; Andreone and Guarino 2003). For sea turtles, skeletochronological studies have been performed, as a rule, on the humerus, because it has the greatest ratio of cortical to cancellous bone and an evident stratification of its bone matrix, which makes the reading of the growth marks feasible (Zug et al. 1986; Avens and Goshe 2007). However, the phalanges of $C$. caretta can also be reliably used (Guarino et al. 2004), while the scleral ossicles in the leatherback turtle, Dermochelys coriacea, are more accurate than the humer- us for assessing individual age (Zug and Parham 1996; Avens et al. 2009). In skeletochronological studies, attention is paid to the identification of lines of arrested growth (LAGs) that are formed yearly, trying to discriminate them from other lines or marks that can form occasionally (supplementary marks, sensu Castanet et al. 1993). The annual LAG deposition is guided by endogenous physiological rhythms synchronised with environmental signals (Simmons 1992; Castanet et al. 1993). For sea turtles, annual periodicity of LAG has been demonstrated for Chelonia mydas (Snover et al. 2011) using vital fluorescent labelling and for $C$. caretta using vital fluorescent labelling (Klinger and Musick 1992; Coles et al. 2001) or known-age samples (Snover and Hohn 2004). Many studies provided validation for carapace length back-calculation from humerus LAG diameter measurements and, therefore, indirectly validated annual LAG deposition (Snover et al. 2007; Goshe et al. 2010; Avens et al. 2012, 2013, 2015, 2017). Thus, it is possible to indirectly estimate the age of the individual from the number of LAGs and to obtain information on the individual's growth rates from the spacing between successive LAGs (Castanet and Smirina 1990). However, the number of LAGs visible may be lower than the number actually formed throughout the turtle's life due to bone remodelling that may partially or totally remove some LAGs. On the other hand, by applying the back-calculation method (Castanet et al. 1993; Guarino et al. 2008) or the correction factor equation (Parham and Zug 1997; Petitet et al. 2012; Turner Tomaszewicz et al. 2015), it is possible to estimate the number of totally resorbed LAGs that must be added to the number of visible LAGs to obtain an accurate age estimation.

The aims of this paper are to: (i) explore the body size distribution and age structure of dead stranded loggerhead turtles on the beaches of Campania using phalangeal skeletochronology; (ii) estimate, for the first time, the age at sexual maturity of both male and female $C$. caretta by matching skeletochronological data to gonad histology; (iii) evaluate the main causes of mortality of the stranded individuals and assess possible relationships between them and particular age/size classes.

\section{Materials and methods}

\section{Sampling}

For age estimation using skeletochronology, we examined 66 phalanges from 65 C. caretta individuals (21 males, 35 females, 9 undetermined sex), dead stranded along the beaches of Campania between March 2013 and May 2017, and 1 from an unsexed individual, held captive from birth until its natural death at the Turtle Rescue Centre of the Zoological Station A, Dohrn, Napoli, Italy (Suppl. material 1: Table S2). The latter individual was held in an outdoor tank during the summer months and inside a greenhouse during the winter months. 
To evaluate reproductive status, we analysed the gross morphology and histology of the gonads of 18 of the stranded individuals.

During necropsy (see below), we measured and recorded for each individual its preservation state, curved carapace length from the nuchal notch to the posterior marginal tip (CCL, in cm) (Bolten 1999), sex, and macroscopic examination of the gonad.

Necropsies followed the procedure in Wolke and George (1981), which, briefly, includes: dissection of the dead animal, macroscopic examination of its organs, collection of tissue samples, and taking measurements of the carcass and internal organs. Causes of death were identified, where possible, and classified into three general categories: 1) unknown), when there was no clear evidence of or cause of death; 2) related to human activities, when there was a clearly identifiable anthropogenic cause such as a boat strike, presence of plastic debris and/or of line and hook in the digestive system; 3) related to infectious and/or parasitic diseases.

Next, from each individual we took the right fore flipper and froze it immediately, while small portions of the gonads were fixed in $10 \%$ buffered formalin and, after 24 hours, stored in $75 \%$ ethanol until laboratory analysis.

\section{Skeletochronology}

Skeletochronological analysis was carried out on phalangeal bone sections prepared according to the standard paraffin embedding technique and sectioned using a rotary microtome (Parham and Zug 1997; Guarino et al. 2019). After being thawed, soft tissues were removed from the fore flipper using a scalpel to take the second phalanx of the third finger (Fig. 1). Before histological preparation, we measured the major and minor axes of each phalanx at the diaphyseal level using a vernier caliper, to the nearest $0.1 \mathrm{~mm}$.

Then the phalanges were fixed in $75 \%$ ethanol and a diaphyseal transverse slice of 3-5 $\mathrm{mm}$ was removed from each of them at the narrowest point using a manual hacksaw. All the slices were decalcified in 5\% nitric acid, following standard protocols (Andreone and Guarino 2003; Guarino et al. 2004; Piovano et al. 2011). The range of decalcification time varied from $5 \mathrm{~h}$ (for the hatchling phalanges) to $28 \mathrm{~h}$, depending mainly on the sample size and its porosity. Phalangeal slices were subsequently washed in running tap water for $12 \mathrm{~h}$, dehydrated through a series of graded ethanol baths, cleared with a terpene of natural origin (Bioclear, Bio Optica, Milan, Italy), and embedded with paraffin of $58^{\circ} \mathrm{C}$ melting point. Phalangeal cross-sections of $15 \mu \mathrm{m}$ thick-

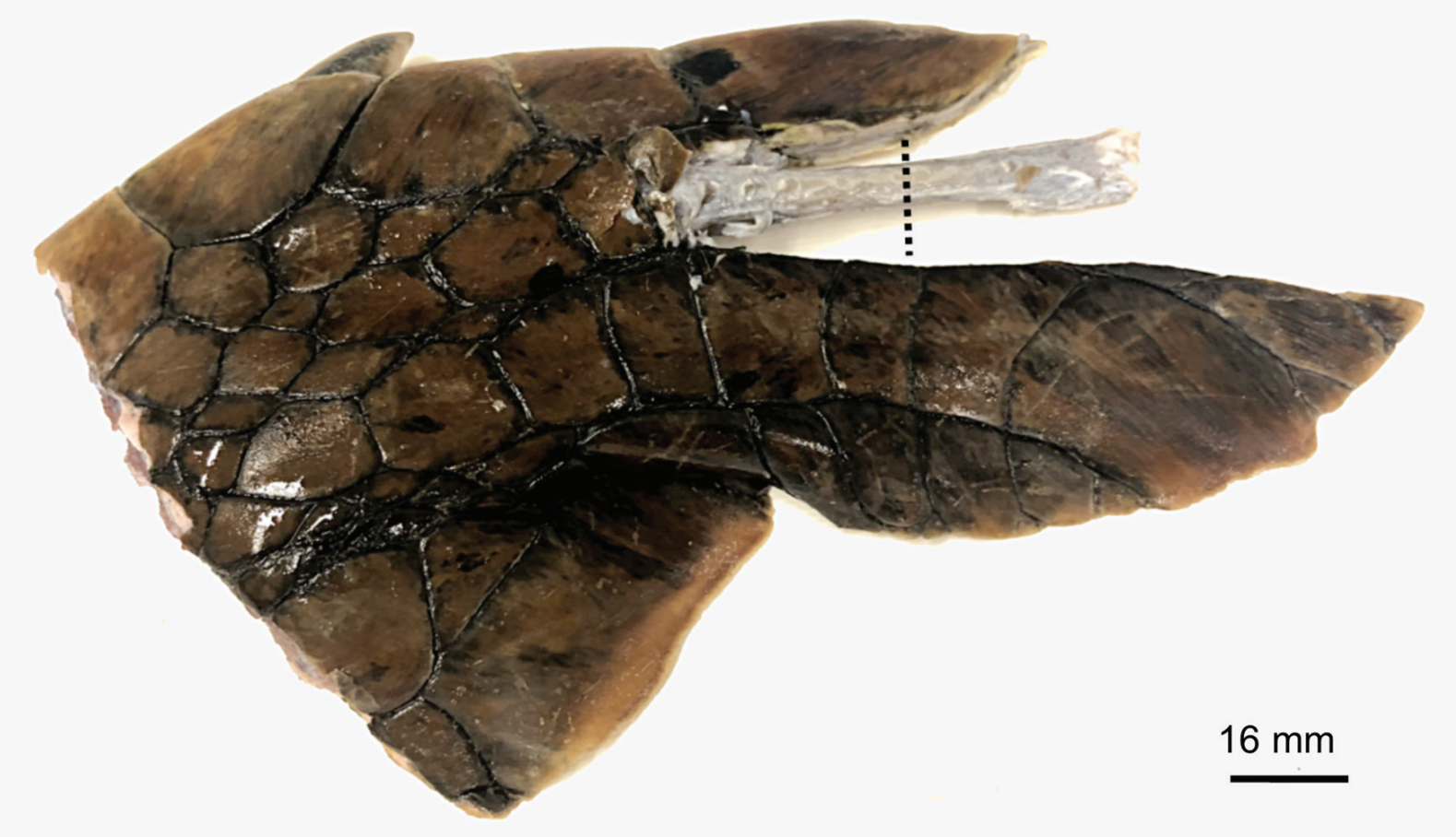

Figure 1. Dorsal view of anterior flipper of C. caretta. The soft tissues have been partially removed from the third finger to expose the phalanx bone. Dotted line shows the level of sectioning, perpendicular to the long axis of phalanx, from which bone sections were obtained. 
ness were obtained with a standard rotary microtome (Reichert-Jung/Leica 2045, Germany) and stained with Mayer's Hematoxylin for $30 \mathrm{~min}$. Stained cross-sections were examined with a Leica EZ4 stereomicroscope to check for the best stained sections and to have an entire histological view of the sections (8-20× magnification). We also observed them with a Motic BA340 light microscope equipped with a digital camera at a higher magnification to better distinguish closely packed LAGs near the cortical bone's outer margin. Following standard protocols (Andreone and Guarino 2003; Piovano et al. 2011; Lenz et al. 2016), the counting of LAGs was performed independently by two researchers (FMG and $\mathrm{NM}$ or FMG and MM) without prior knowledge of the CCL and sex of the specimens. In the case of discrepancies in LAG count, the sections were read again until consensus was reached. The digital images of the bone sections were optimised, with respect to contrast and intensity, using Adobe Photoshop 6.0 (Adobe Systems Incorporated, San José, California, USA), to enhance the distinctiveness of LAGs. When a LAG appeared to be split into two or more lines, each line was counted as a single LAG. To assess the number of LAGs totally removed by bone remodelling, which progresses centrifugally from the core of the diaphysis, we applied the back-calculation method (Avens and Snover 2013; Avens et al. 2017), using software Image J 1.52a (National Institute of Health, USA). In particular, the diameter of all the visible LAGs and that of the external diaphyseal cortical margin were measured in the phalanx sections of the smaller individuals $(\mathrm{CCL}<40 \mathrm{~cm})$, where no LAGs were lost, and the measurements thus obtained were compared with the diameters of the innermost, measurable LAGs of the larger individuals. All the variables compared represented the mean \pm 2 standard deviations (SDs) of three measurements conducted on three different sections. If the difference between the diameter of the innermost visible LAG of an individual with CCL > $40 \mathrm{~cm}$ and the diameter of the external diaphyseal margin of a smaller individual exceeded $2 \mathrm{SD}$, we inferred that the number of totally lost LAGs in the larger individual was equal to the number observed in the smaller individual. The inferred number of lost LAGs was then added to the number of visible LAGs to estimate the actual age of the largest individuals.

Concerning the validation of the skeletochronological method, our study sample included the phalanges of two dead animals of known age: a hatchling $(\mathrm{CCL}=5.6 \mathrm{~cm})$, and an individual raised in captivity for 16 months (CCL $=14.1 \mathrm{~cm}$ ) (see above and Suppl. material 1: Table S2). Furthermore, we reworked the skeletochronological data of Di Maio et al. (2003) and our unpublished data in order to compare the LAG number detected in the humerus and phalanx of the same individual $(n=13)$.

Among 66 phalanges examined there were also those of a turtle that was tagged and released on 28.09.2013 (Mondello, Palermo) with $\mathrm{CCL}=63.4 \mathrm{~cm}$ and found dead on 24.03.2014 with $C C L=63.5 \mathrm{~cm}$.

\section{Analysis of age at maturity}

Gonads were examined macroscopically; they were then processed using the paraffin embedding technique described above, but without the preliminary decalcification of the tissues. The sections, $7 \mu \mathrm{m}$ thick, were stained with Mallory Trichrome (Bioptica, Milano) and observed under a Motic BA340 light microscope. Males were considered sexually mature if their testes contained spermatozoa and/or there was evidence of spermatogenetic stages, starting from spermatocytogenesis (Meylan et al. 2002). Females were considered sexually mature if their ovaries contained advanced vitellogenetic follicles and/or residual post-ovulatory follicles according to the criteria in Perez-Bermudez et al. (2012).

\section{Statistical analyses}

We used Student's test or the Mann-Whitney non-parametric test to compare two independent groups, depending on whether data were normally distributed or not (Kolmogorov-Smirnov test). Spearman's rank test and linear regression were used to evaluate the relationship between CCL and age. A probability level of $p<0.05$ was considered significant.

\section{Results}

\section{Body size distribution}

The CCL of all examined turtles ranged from 5.6 (hatchling) to $90.8 \mathrm{~cm}$ (female adult). Nine turtles were not sexed, owing to the advanced state of decomposition. The CCL mean $\pm \mathrm{SD}$ was $65.9 \pm 8.3 \mathrm{~cm}$ in males $(n=22)$ and $66.2 \pm 11.3 \mathrm{~cm}$ in females $(n=35)$ (Fig. 2). The CCL means did not differ significantly between the sexes (unpaired t-test, $t=0.09, \mathrm{DF}=55, p=0.92$ ).

\section{Phalanx histological characteristics and growth marks}

Cross-section of the phalanx at the diaphyseal level was formed of an outer cortex and an inner medulla. In specimens with $\mathrm{CCL}<30 \mathrm{~cm}$, the cortex was mostly vascularised, whereas the medulla was partially filled with trabecular bone (Fig. 3A, B). In specimens with $\mathrm{CCL}>30 \mathrm{~cm}$, the cortex was compact and poorly vascularised, whereas the medulla was completely filled with trabecular bone without the formation of a well-defined medullary cavity (Fig. 3C, D).

Both the cortex and medulla were formed essentially by the deposition of parallel-fibered bone. However, the bone layering was distinct in the cortex (Fig. 3A, C), whereas it was strongly altered in the medulla due to remodelling processes with an enlargement of the blood 


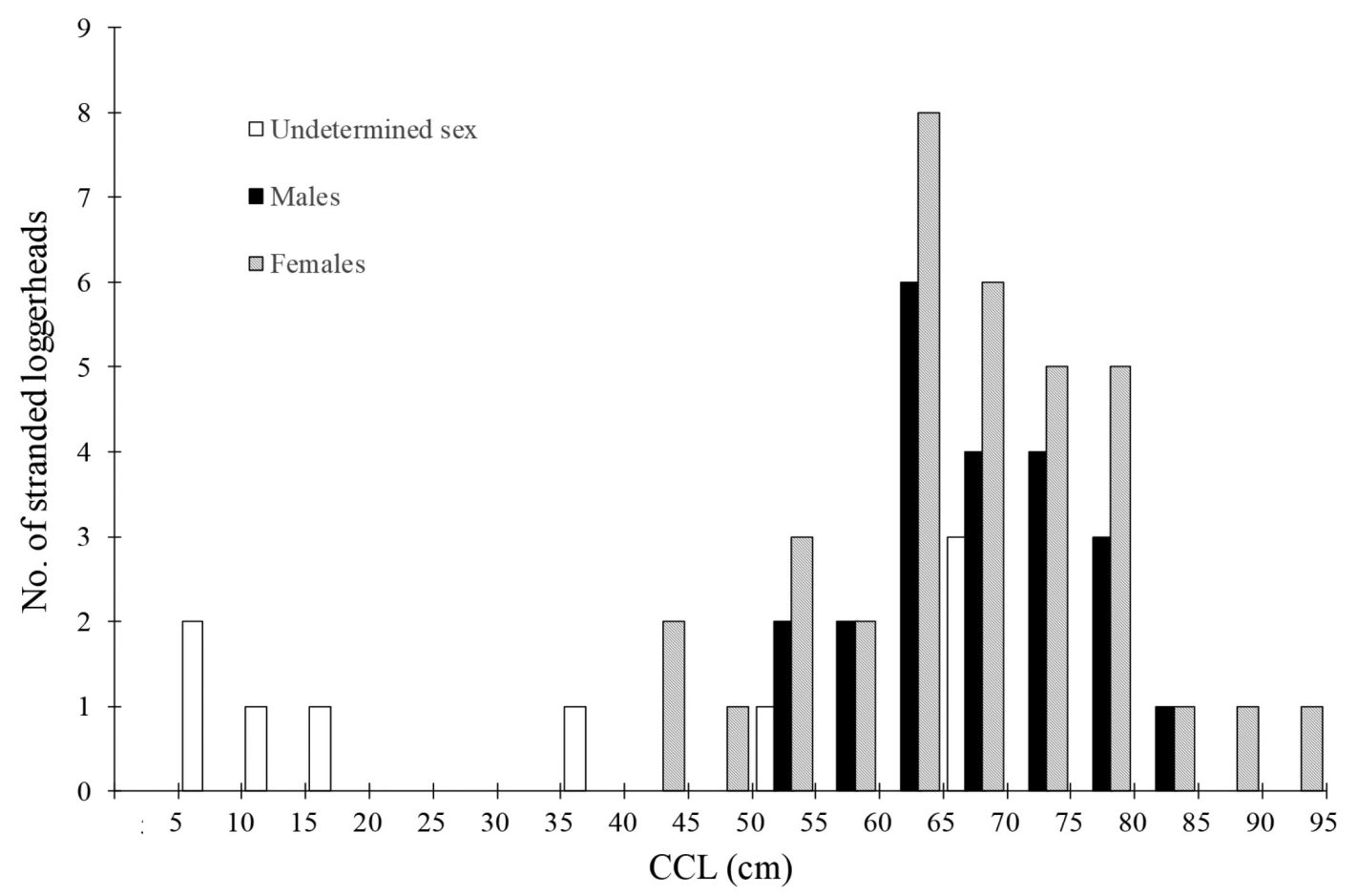

Figure 2. Body size (CCL, in $\mathrm{cm})$ distribution of sampled C. caretta.
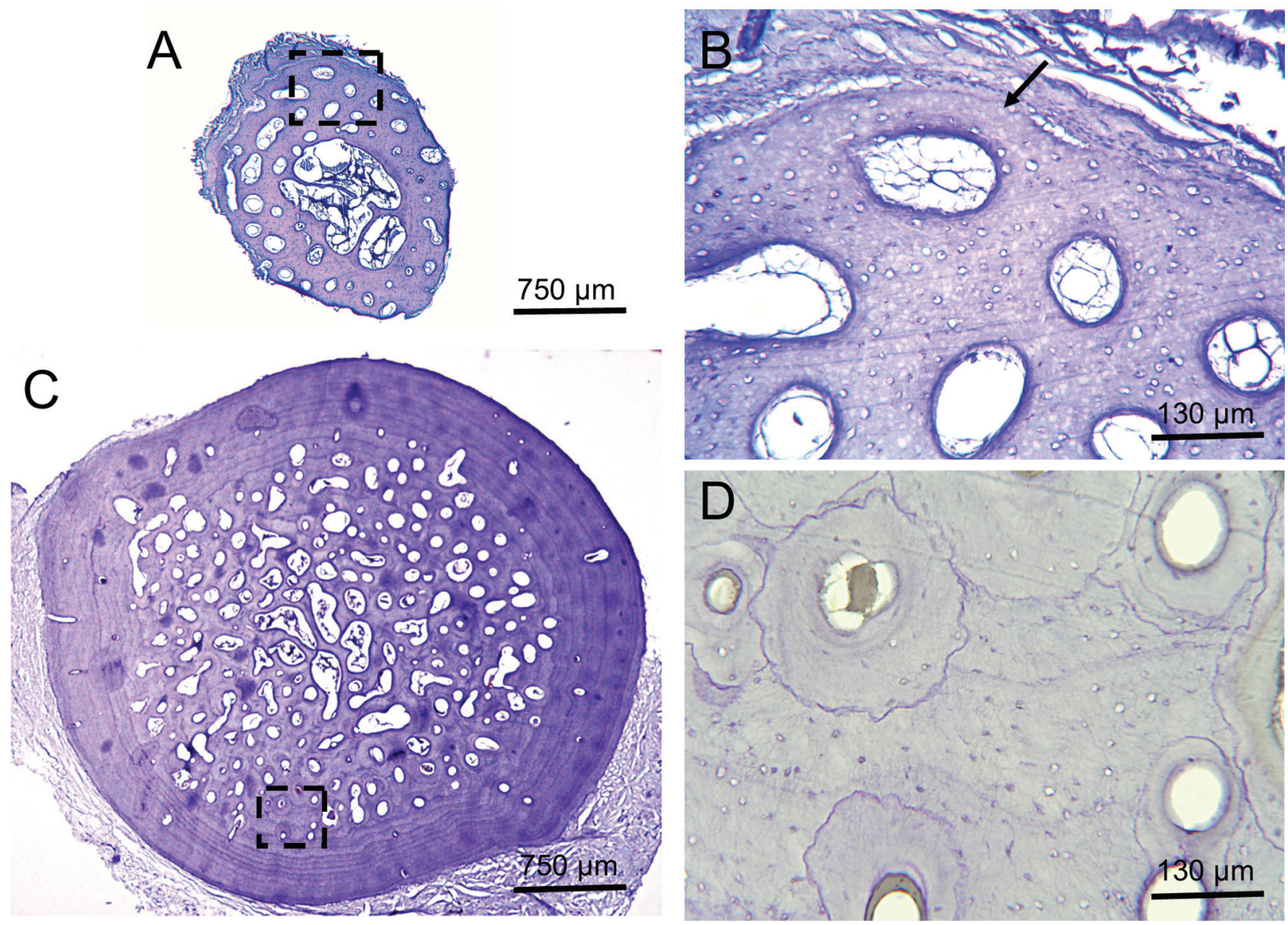

Figure 3. Representative phalanx cross-sections at the diaphyseal level of C. caretta. A) ID36910, in captivity for 16 months, undetermined sex, $\mathrm{CCL}=14 \mathrm{~cm}$. B) Higher magnification of the dashed square shown in Fig. A): note one LAG at outer bone margin (arrow). C) ID 69155, female, $\mathrm{CCL}=80.5 \mathrm{~cm}$. D) Higher magnification of the dashed square shown in Fig. C) showing some Haversian systems. 

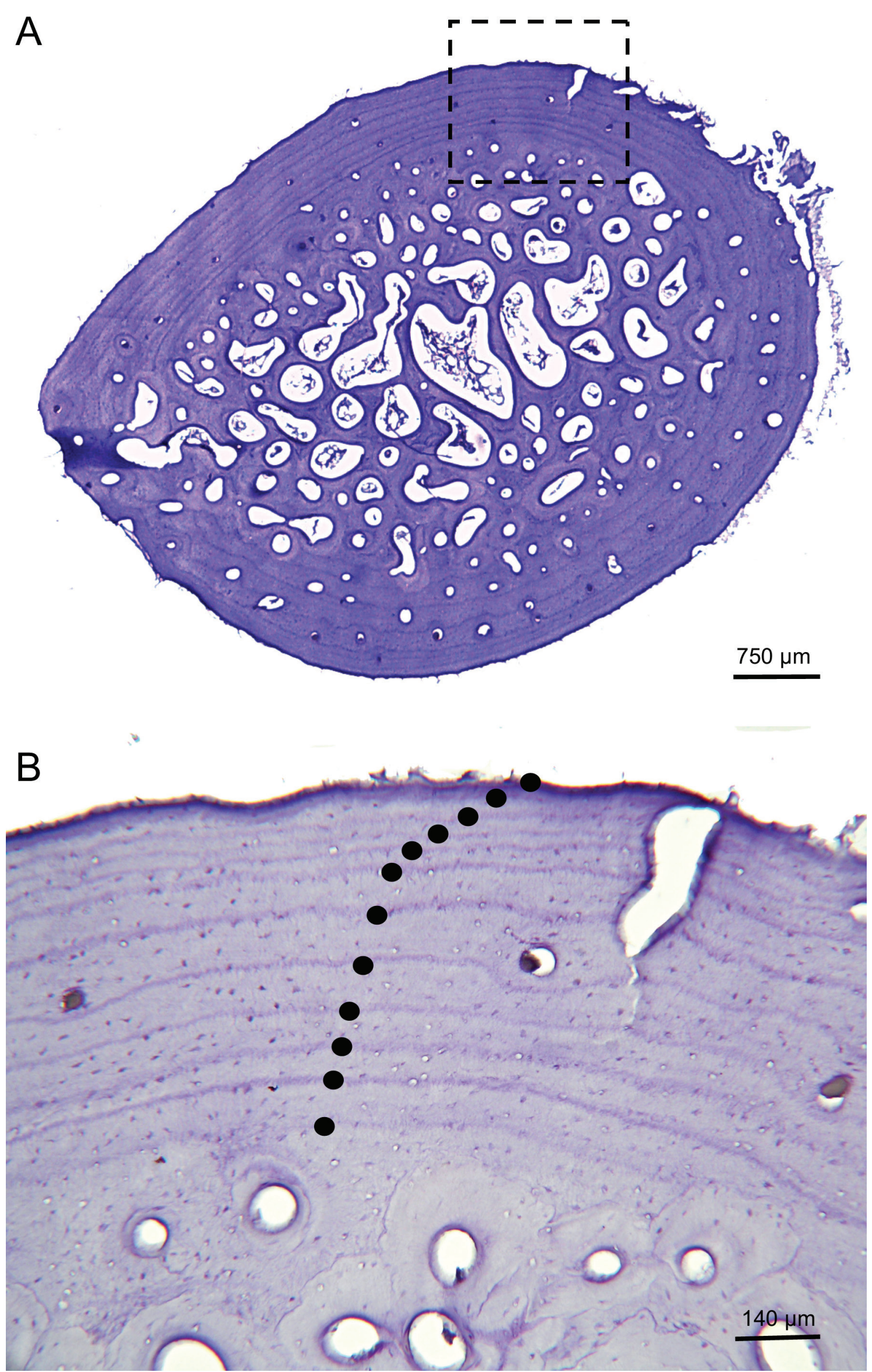

Figure 4. Representative phalanx cross-sections at the diaphyseal level of C. caretta. A) ID 123825, male, CCL $=66 \mathrm{~cm}$. B) Higher magnification of the dashed square shown in Fig. A); the black circles indicate the lines of arrested growth (LAGs). 
vessels and formation of Haversian systems (Fig. 3D). Distinct LAGs were observed in all the phalangeal sections analysed (Fig. 4A, B) except in the hatchling, as expected. The turtle held in captivity for 16 months, with $\mathrm{CCL}=14.1 \mathrm{~cm}$, had one $\mathrm{LAG}$, which was close to the outer cortical margin (Fig. 3B). Two wild turtles, with CCLs $=9.8 \mathrm{~cm}$ and $16.0 \mathrm{~cm}$, also had only $1 \mathrm{LAG}$ each. Therefore, all these specimens were considered not to have resorbed LAGs during bone growth. The turtle from Palermo stranded with $\mathrm{CCL}=63.5 \mathrm{~cm}$ had the last LAG confluent with the outer bone margin.

For the 50 individuals with $\mathrm{CCL}>16 \mathrm{~cm}$, the number of visible LAGs were $3-15$ (mean $=9.5 \pm 2.7 \mathrm{SD})$ and the number of lost LAGs were $2-16$ (mean $=8.4 \pm 4.3 \mathrm{SD})$.

\section{Age estimation}

Eleven $(85 \%)$ out of thirteen specimens used for skeletochronological comparison of different bones showed an identical number of LAGs in the phalanx and humerus (Table 1), while two specimens (15\%) differed by only one LAG, indicating that skeletochronology of phalanges is a reliable method for age estimation for $C$. caretta.

Precise age estimation (number of visible LAGs + number of lost LAGs) was obtained for 59 (90\%) out of 66 turtles of the study sample. In two males and five females, age was estimated with an error of 1-6 years due to extensive bone remodelling that did not allow an accurate estimation of the number of lost LAGs. These individuals, including some of the largest specimens (a male with $\mathrm{CCL}=80 \mathrm{~cm}$ and 25-30 LAGs; a female with $\mathrm{CCL}=90 \mathrm{~cm}$ and 24-30 LAGs), were excluded from subsequent analyses. Age ranged from 10 to 26 years for males (mean \pm SD: $17.35 \pm 4.2, n=20$ ) and 7 to 26 years
Table 1. Number of visible LAGs in phalanx (phal) and humerus (hum) sections of Caretta caretta. CCL - curved carapace length (in cm) (reworked from Di Maio et al. 2003, and authors'unpublished data).

\begin{tabular}{lccc}
\hline \multicolumn{1}{c}{ ID } & CCL & Phal & Hum \\
\hline 00826.0 & 14.0 & 2 & 2 \\
990802.1 & 19.0 & 3 & 3 \\
990727.1 & 20.0 & 4 & 4 \\
990723.1 & 24.0 & 5 & 5 \\
990725.0 & 28.0 & 5 & 5 \\
00801.3 & 42.0 & 6 & 6 \\
010804.0 & 42.0 & 6 & 6 \\
00802.2 & 46.0 & 7 & 7 \\
011115.0 & 49.0 & 8 & 8 \\
011115.2 & 51.0 & 8 & 8 \\
IT $431 / 432$ & 53.0 & 13 & 14 \\
001214.0 & 61.0 & 14 & 15 \\
000806.1 & 68.0 & 15 & 15 \\
\hline
\end{tabular}

for females (mean $\pm \mathrm{SD}$ : $17.1 \pm 5.0, n=30$ ), and did not significantly differ between the sexes (Mann-Whitney U-test, $U=289, p=0.834$ ). The modal age was 14 years for males and 17 years for females (Fig. 5), but a similar percentage of adult males (25\%) and females (26\%) were older than 20 years.

Both sexes exhibited a highly significant positive correlation between age and CCL (Spearman's rank test: males, $r_{s}=0.87, n=20, p<.0001$; females, $r_{s}=0.85, n=$ $30, p<0.0001$ ) (Fig. 6).

\section{Cause of death}

Excluding the specimens without a precise age estimation $(n=7)$, of the 59 turtles necropsied, 21 (10 males, 10 females, 1 unsexed, $\sim 36 \%$ ) had their death attributed to

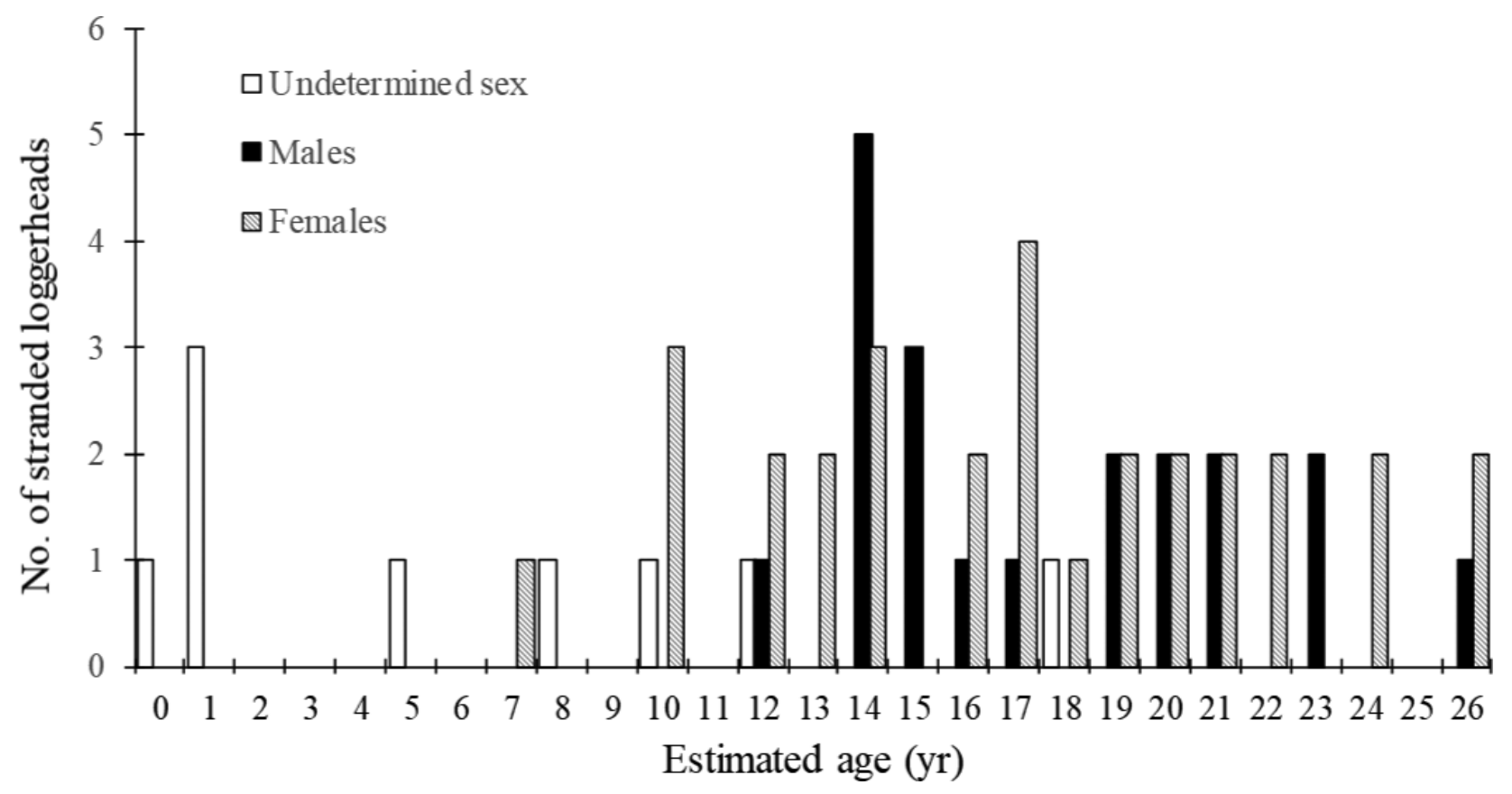

Figure 5. Estimated age distribution of $C$. caretta using phalangeal skeletochronology. 


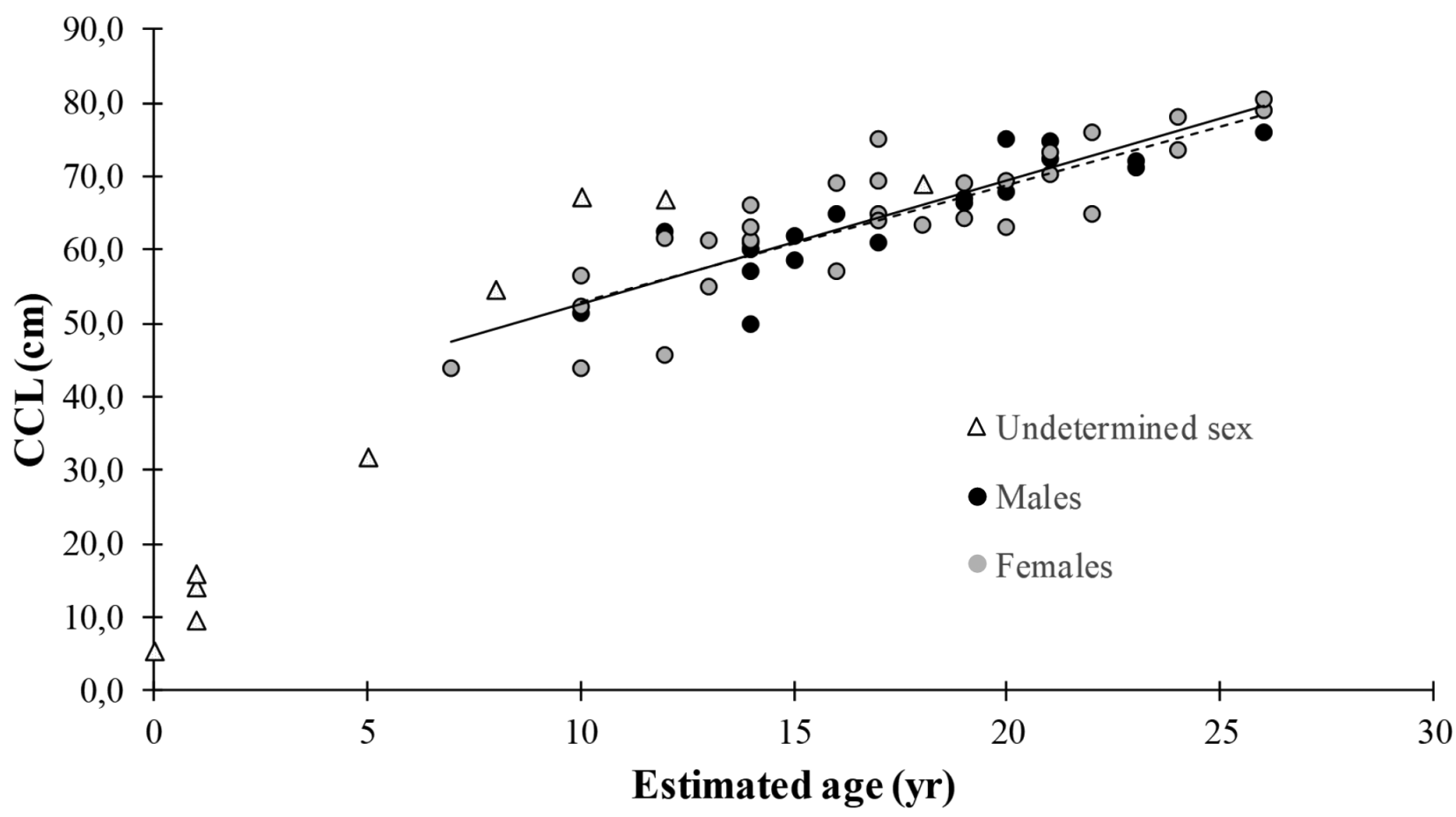

Figure 6. Relationship between age (years) and body size (CCL, in $\mathrm{cm})$ in C. caretta. The dashed line and the dotted line represent linear regression for males and females, respectively.

anthropogenic causes and 12 (5 males, 4 females, 3 ND, $\sim 20 \%$ ) to parasitic/infective pathologies. For 26 specimens ( $\sim 4 \%$ ), we could not identify cause of death. Three out of five individuals aged 1-5 years died from parasitic/infective pathologies, while the majority of older specimens died from anthropogenic causes (see Suppl. material 1: Table S3). Injuries by hook and line were the most common anthropogenic cause of death $(n=13)$, followed by boat strike $(n=7)$ and ingestion of plastic debris $(n=1)$. However, for both sexes, we did not find any relation between age and specific cause of mortality (Suppl. material 1: Table S3).

\section{Age at maturity}

About half of the examined gonads were in an advanced autolytic state, with altered tissue organisation due to a poor state preservation, so their gametogenic stage could not be evaluated (Suppl. material 1: Table S4; Fig. 7). In only three females (with CCLs $=69.5 \mathrm{~cm}, 55.6 \mathrm{~cm}$ and $61.3 \mathrm{~cm}$ ) of the 11 examined, the ovary was in a good preservation state to determine accurately the stage reached in the ovarian cycle (Fig. 7A, B). However, we could also use the ovaries of five females with several follicles only partially affected by the autolytic process and-assess the stages of their ovarian cycle. The smallest female with ovaries showing follicular development stage during transition to adulthood had CCL $=69.5 \mathrm{~cm}$ and was estimated to be 20 years old. For the males, it was possible to recognise the stage of the spermatogenetic cycle in three out of the seven individuals analysed (Fig.7D). The smallest male with mature gonads had a $C C L=65 \mathrm{~cm}$ and was estimated to be 16 years old. The latter, although showing the testicles in autolysis, had seminiferous tubules with large lumen diameters, suggesting the occurrence of active spermatogenesis (Fig. 7E).

\section{Discussion}

The body size range $(\mathrm{CCL}=5.6-90 \mathrm{~cm})$ of the stranded loggerhead turtles from this study was similar to those reported from around the western Mediterranean Sea $(\mathrm{CCL}=7-83 \mathrm{~cm}$ in Guarino et al. 2004; 13-78.9 cm in Piovano et al. 2011; 24-86.5 cm in Casale et al. 2011b). However, the majority of the specimens analysed in this study $(\sim 82 \%)$ fell between 50 and $79.9 \mathrm{~cm}$ CCL. We hypothesise that this body size range characterises the neritic stage of $C$. caretta in the western Mediterranean Sea and that individuals with CCL $<50 \mathrm{~cm}$ or $>80 \mathrm{~cm}(18 \%$ of our sample) can only be found occasionally. However, our study was conducted only on dead stranded turtles, and mark-recapture and length frequency study are necessary to confirm our findings.

Interestingly, the sex ratio was clearly female-biased $(\sim 1.5: 1)$, for individuals whose sex could be determined. The strong predominance of females has also been reported in stranded green turtles Chelonia mydas (Mascarenhas et al. 2005; Failla et al. 2018), and in a long-term study on live C. caretta (McNeill et al. 2016). Unfortunately, we cannot explain the unbalanced sex ratio of the $C$. caretta specimens studied by us. In general, species that exhibit environmental sex determination show skewed sex ratios more frequently than species that exhibit genotypic sex determination (Bull 1980). In the Mediterranean, 

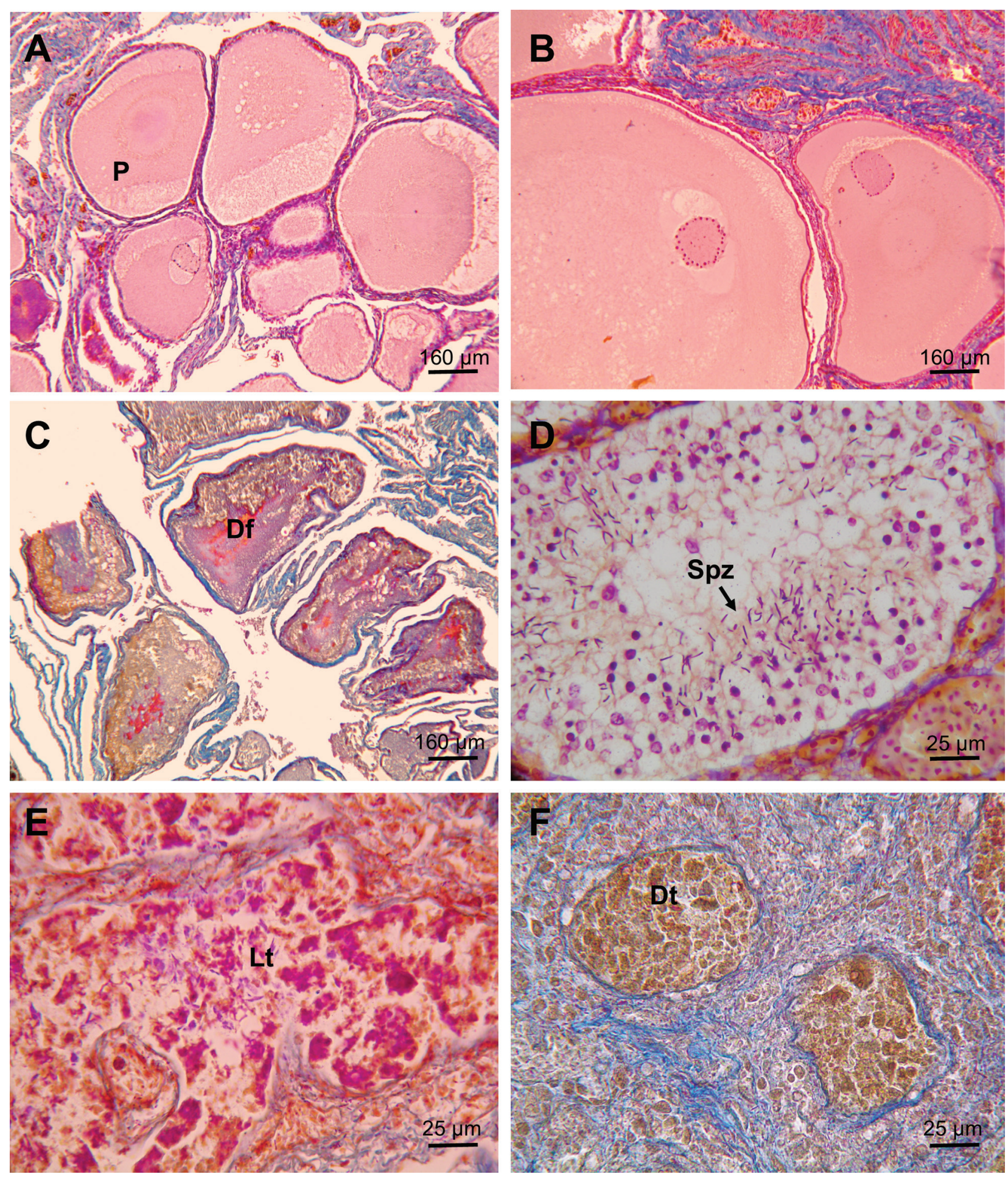

Figure 7. Representative ovary (A-C) and testis (D-E) cross-sections of C. caretta, stained using Mallory's trichrome stain. A) ID 62083: previtellogenic follicles in different developmental stages. B) ID 53439: follicles with strongly increased diameter at the end of previtellogenesis stage. C) ID 72818: degenerated follicles due to autolysis. D) ID 50816: seminiferous tubule showing active spermatogenesis, including spermatozoa. E) ID 100276: seminiferous tubule degenerating by autolysis and with large lumen. F) ID 123825: degenerated seminiferous tubules with abundant interstitial tissue. Df: degenerated follicles; Dt: degenerated seminiferous tubules: Lt: lumen of the seminiferous tubule; P: previtellogenic follicles; Spz: spermatozoa.

juvenile and adult sex ratios of $C$. caretta do not differ significantly from 1:1, although estimates of hatchling sex ratios are highly female-biased (Maffucci et al. 2013; Casale et al. 2014). In addition, juvenile sex ratios in the
Mediterranean are largely unaffected by immigration of Atlantic individuals into the Mediterranean, as previously suggested (Maffucci et al. 2013). However, it is difficult to understand the possible causes of unbalanced sex ra- 
tio of species with a complex life cycle, such as sea turtles, by just collecting data on sex (Casale et al. 2006). In fact, a correct interpretation of sex ratios needs additional knowledge on distribution, movement and origin of sea turtles. Therefore, more targeted research is required in response to our findings. However, for species that exhibit temperature-dependent sex determination (TSD), e.g. sea turtles, higher environmental temperatures may lead to single-sex populations and, ultimately, population extinction (Hays et al. 2017). Although for sea turtles these concerns are currently speculative, they may become more relevant under extreme global warming scenarios (Hays et al. 2017).

So far, skeletochronology in sea turtles has used the humerus because it exhibits a lower resorption rate than other skeletal elements, the strong foundation of methodology and the large sample sizes for establishing correction factors to estimate the number of resorbed LAGs and the ability to back-calculate somatic growth rates (Avens and Snover 2013). Although previous papers present the use of ground or polished humerus cross sections for skeletochronological analysis, currently recommended and generally accepted methods involve the preparation of stained sections of decalcified humerus and always present the opportunity to evaluate multiple, sequential sections to find the best one to be used for analysis (Goshe et al. 2009; Avens and Snover 2013). On the other hand, the potential for a reliable skeletochronology of the phalanx, previously suggested by Di Maio et al. (2003), has been confirmed here on 13 individuals of $C$. caretta where the number and pattern of LAGs observed in the humerus and phalanx of each individual were consistent. In addition, the use of the phalanx instead of the humerus provides practical and technical advantages in skeletochronology because it requires shorter preparation times of decalcified sections. Furthermore, the phalanx, unlike larger bones, would not limit the size of the sample that can fit in the embedding mould and/or in the microtome; it allows the preparation of many serial sections that can be observed and compared, which is essential for a correct and unambiguous age estimation. The main difficulty encountered during this study was the complete loss of LAGs due to bone remodelling. Indeed, the phalanx of $C$. caretta shows strong resorption within the diaphyseal core but retains the periosteal layering on a wide part of the cortex. Therefore, as for the humerus (Aven and Snover 2013), for most individuals it was possible to estimate the number of lost LAGs from the width of the extant LAGs and for most of the phalangeal sections our results are unambiguous and show that the phalanx can be a useful tool for skeletochronological analysis of $C$. caretta. Further work aimed at establishing standard phalangeal section measurements and relating those to carapace length, will allow to use the phalanges for somatic growth rate back-calculation.

Different approaches have been used to estimate the age of $C$. caretta. in the Mediterranean Sea, including capture-mark-recapture (Casale et al. 2009), tail measure- ments (Casale et al. 2005), and skeletochronology (Casale et al. 2011a; Piovano et al. 2011). Our skeletochronological age estimation partially agrees with the results obtained from the skeletochronology of loggerhead turtles stranded in other Mediterranean areas and highlights the variability in the age of $C$. caretta in the studied marine area. In fact, the age of loggerhead turtles with CCL $=40-80$ $\mathrm{cm}$, for which it is possible to make comparisons, ranged from 7-26 years in our study, 7-19 years in Casale et al. (2011a), and 9-30 years in Piovano et al. (2011). Although based on dead stranded animals, our data are in accordance with current knowledge on the general life history patterns of sea turtles in indicating that, excluding the single case of a 7-year-old female, the recruitment of juveniles from oceanic habitat to the neritic habitat in the Mediterranean usually starts after 10 years. In addition, during the neritic stage, the majority of the Mediterranean C. caretta are 10 20 years old, rarely exceed 20 years, and even more rarely reach 30 years. However, it should be noted that different growth rates have been reported for loggerhead turtles of either Mediterranean or Atlantic origin (Piovano et al. 2011). We have not performed genetic analyses to find out the origins of the specimens we have studied, and it cannot be excluded that different origins may have influenced the overall age estimation of our sample.

So far, a variety of methods, including mark and recapture, length frequency and skeletochronology, have been used to estimate the age at maturity of $C$. caretta and other sea turtle species (Avens and Snover 2013; Avens et al. 2015; Turner Tomaszewicz et al. 2015). However, except for the study by Avens et al. (2015), data on the age at maturity of $C$. caretta usually concern only the females or combine the sexes (see Avens and Snover 2013), and are based on body size and age at first nesting. The estimates of the age at maturity reported in the literature show a varied picture, ranging from 14.9-29.3 years $(\mathrm{CCL}=66.5$ $87.7 \mathrm{~cm}$ ) for the Mediterranean, 10-38.9 years $(\mathrm{CCL}=$ 86-102.5 cm) for the Atlantic, and 25-36 years (CCL $\leq$ $91.5 \mathrm{~cm}$ ) for the Pacific population (Avens and Snover 2013; Turner Tomaszewicz et al. 2015). Our study reports the first data on the age at maturity based on the gonadal histology of both sexes of $C$. caretta. We have shown that males are potentially able to breed at 16 years, at $\mathrm{CCL}=65$ $\mathrm{cm}$, whereas females attain sexual maturity at 20 years, at $\mathrm{CCL}=69 \mathrm{~cm}$. For females, our estimates of the minimum age at sexual maturity are in accord with those by Piovano et al. (2011) and higher than the results reported by Casale et al. (2011a). Unfortunately, the poor state of preservation of the gonads of stranded turtles with CCL $<69 \mathrm{~cm}$ did not allow us to verify whether the average size and age at first maturity could be lower than we have reported. On the other hand, our gonad sample size was small (only $1 / 6$ of all examined turtles provided reliable data to assess maturation state) and further research is needed to confirm our findings. However, to the best of our knowledge, the study by Avens et al. (2015), performed on $C$. caretta specimens stranded along the Atlantic USA coast, is the only one in which the age of sexual maturity is es- 
timated separately for males and females using different approaches involving skeletochronological data. In this study, the mean age predictions associated with minimum and mean maturation SCLs (straightline carapace length) were 22.5-25 and 36-38 years for females and 26-28 and $37-42$ years for males, respectively. The broad total range of potential age at sexual maturity indicates the absence of a knife-edge maturation threshold for the different populations of $C$. caretta (Avens et al. 2015).

Interestingly, the two main categories of causes of mortality (anthropogenic causes and parasitic/infective pathologies) threaten a range of age and size individuals of $C$. caretta in Campanian waters. Excluding the individuals $\leq 5$ years which prevalently died from parasitic/ infective pathologies ( 3 out of 5 individuals), a clear correlation between distinct death causes and different age classes was not found. However, considering the sample size for which it was possible to determine the cause of death using necropsy $(n=33)$, our data strongly emphasise that anthropogenic causes, such as hook and line and boat collisions, represent the more frequent threat (64\%) for the loggerhead turtle in southern Italian waters (see Suppl. material 3:Table S3).

In conclusion, using phalangeal skeletochronology, we assessed the age of the loggerhead sea turtles, $C$. caretta, stranded from 2013 to 2017 on southwestern Italian beaches (western Mediterranean). Furthermore, we also obtained data on the age at maturity by histologically examining gonad samples for about $1 / 3$ of the studied animals $(n=66)$. Our findings on individual age partially agree with those of previous studies on $C$. caretta in the Mediterranean Sea and indicate that, at the neritic stage, the ages of most Mediterranean loggerhead turtles range between 10 and 20 years; less frequently it falls between 20 and 30 years. Data from gonadal histology suggest that males attain sexual maturity a little earlier than females (at 16 and 20 years respectively), but in both sexes it is after reaching a $\mathrm{CCL}>65 \mathrm{~cm}$.

\section{Acknowledgments}

This research is part of the activities under a broad Memorandum of Understanding including the University of Naples Federico II and the Istituto Zooprofilattico del Mezzogiorno, Portici (Naples), ratified by decree N.98 of 08/11/2009 of the Regional Council of Campania (Italy) and updated with decree N. 231 of 15/07/2015.

We are grateful to Marianna Esposito and Ilaria Iavarone for assistance in histological preparation. We thank Daniela Freggi of the WWF Italy Rescue Center of Lampedusa (Agrigento, Italy) and Paolo Casale (University of Pisa, Italy) for providing data about the tagged turtle ID 5086A. We also thank Gennaro Elefante and Angelo Elefante of CSEM (Associazione Centro Studi Ecosistemi Mediterranei) (Pioppi, Acciaroli, Salerno) for support in field survey. We thank two anonymous reviewers for providing comments that improved this manuscript.

\section{References}

AndreoneF, GuarinoFM(2003)Giantandlong-lived:agestructure in Macroscincus coctei, an extinct skink from Cape Verde. Amphibia-Reptilia 4: 459-470. https://doi.org/10.1163/156853803322763927

Avens L, Goshe LR, Coggins L, Shaver DJ, Higgins B, Landry Jr AM, Bayley R (2017) Variability in age and size at maturation, reproductive longevity, and long-term growth dynamics for Kemp's ridley sea turtles in the Gulf of Mexico. PLoS ONE 12 (3): e0173999. https://doi.org/10.1371/journal.pone.0173999

Avens L, Goshe LR, Coggins L, Snover ML, Pajuelo M, Bjorndal KA, Bolten AB (2015) Age and size at maturation- and adult-stage duration for loggerhead sea turtles in the western North Atlantic. Marine Biology 162: 1749-1767. https://doi.org/10.1007/s00227-015-2705-X

Avens L, Goshe LR, Harms CA, Anderson ET, Hall AG, Cluse VM, Godfrey MH, Braun MC, Neill J, Stacy B, Bayles R, Lamont MM (2012) Population characteristics, age structure, and growth dynamics of neritic juvenile green turtles in the northeastern Gulf of Mexico. Marine Ecology Progress Series 458: 213-229. https://doi. org/10.3354/meps09720

Avens L, Goshe LR, Pajuelo M, Bjorndal KA, MacDonald BD, Lemoms GE, Bolten AB, Seminoff JA (2013) Complementary skeletochronology and stable isotope analyses offer new insight into juvenile loggerhead sea turtle oceanic stage duration and growth dynamics. Marine Ecology Progress Series 491: 235-251. https:// doi.org/10.3354/meps 10454

Avens L, Snover ML (2013) Age and age estimation in sea turtles. In: Wyneken J, Lohmann KJ, Musick JA (Eds) The Biology of Sea Turtles (Vol. III). CRC Press, Boca Raton, 97-134. https://doi. org/10.1201/b13895

Avens L, Taylor JC, Goshe LR, Jones TT, Hastings M (2009) Use of skeletochronological analysis to estimate the age of leatherback sea turtles Dermochelys coriacea in the western North Atlantic. Endangered Species Research 8: 165-177. https://doi.org/10.3354/esr00202

Blackburn D (2006) Squamate reptiles as model organisms for the evolution of viviparity. Herpetological Monographs 20: 131-146. https:// doi.org/10.1655/0733-1347(2007)20[131:SRAMOF]2.0.CO;2

Bolten AB (1999) Techniques for measuring sea turtles. In: Eckert KL, Bjorndal KA, Abreu-Grobois FA, Donnelly M (Eds) Research and Management Techniques for the Conservation of Sea Turtles. IUCN/ SSC Marine Turtle Specialist Group, 110-114.

Bull JJ (1980) Sex determination in reptiles. Quarterly Review of Biology 55: 3-21. https://doi.org/10.1086/411613

Camargo A, Sinervo B, Sites Jr JW (2010) Lizards as model organisms for linking phylogeographic and speciation studies. Molecular Ecology 19: 3250-3270. https://doi.org/10.1111/j.1365294X.2010.04722.x

Casale P, Affronte M, Insacco G, Freggie D, Vallini C, Pino D'astore P, Basso R, Paolillo G, Abbatei G, Argano R (2010) Sea turtle strandings reveal high anthropogenic mortality in Italian waters. Aquatic Conservation: Marine and Freshwater Ecosystems 20: 611-620. https://doi.org/10.1002/aqc.1133

Casale P, Conte N, Freggi D, Cioni C, Argano R (2011a) Age and growth determination by skeletochronology in loggerhead sea turtles (Caretta caretta) from the Mediterranean Sea. Scientia Marina 75: 197-203. https://doi.org/10.3989/scimar.2011.75n1197

Casale P, Freggi D, Basso R, Argano R (2005) Size at male maturity, sexing methods and adult sex ratio in loggerhead turtles (Caretta caretta) 
from Italian waters investigated through tail measurements. Herpetological Journal 15: 145-148.

Casale P, Freggi D, Maffucci F, Hochscheid S (2014) Adult sex ratios of loggerhead sea turtles (Caretta caretta) in two Mediterranean foraging grounds. Scientia Marina 78: 303-309. https://doi.org/10.3989/ scimar.03988.30E

Casale P, Laurent L, De Metrio G (2004) Incidental capture of marine turtles by the Italian trawl fishery in the north Adriatic Sea. Biological Conservation 119: 287-295. https://doi.org/10.1016/j.biocon.2003.11.013

Casale P, Lazar B, Pont S, Tomàs J, Zizzo N, Allegre F, Badillo J, Di Summa A, Freggi D, Lackovic G, Raga JA, Rositani L, Tvrtkovi'c N (2006) Sex ratios of juvenile logggerhead sea turtles Caretta caret$t a$ in the Mediterranean Sea. Marine Ecology Progress Series 324: 281-285. https://doi.org/10.3354/meps324281

Casale P, Mazaris AD, Freggi D (2011b) Estimation of age at maturity of loggerhead sea turtles Caretta caretta in the Mediterannean using length frequency data. Endangered Species Research 13: 123-129. https://doi.org/10.3354/esr00319

Casale P, Mazaris AD, Freggi D, Vallini C, Argano R (2009) Growth rates and age at adult size of loggerhead sea turtles (Caretta caretta) in the Mediterranean Sea, estimated through capture-mark-recapture records. Scientia Marina 73: 589-595. https://doi.org/10.3989/scimar.2009.73n3589

Casale P, Tucker AD (2017) Caretta caretta (amended version of 2015 assessment). The IUCN Red List of Threatened Species 2017: e.T3897A119333622. https://doi.org/10.2305/IUCN.UK.2017-2. RLTS.T3897A119333622.en [Downloaded on 02 June 2019]

Castanet J (1994) Age estimation and longevity in reptiles. Gerontology 40: 174-92. https://doi.org/10.1159/000213586

Castanet J, Francillon-Vieillot H, Meunier FJ, de Ricqles A (1993) Bone and individual aging. In: Hall BK (Ed.) Bone Growth (Vol. 7). CRC, Boca Raton, 245-283.

Castanet J, Smirina E (1990) Introduction to the skeletochronological method in amphibians and reptiles. Annales Sciences Naturelles Zoologie 13: 191-196.

Coles WC, Musick JA, Williamson LA (2001) Skeletochronology validation from an adult loggerhead (Caretta caretta). Copeia 2001: 240-241. https://doi.org/10.1643/0045-8511(2001)001[0240:SVFAAL]2.0.CO;2

de Miranda EBP (2017) The plight of reptiles as ecological actors in the tropics. Frontiers in Ecology and Evolution 5: 1-159. https://doi. org/10.3389/fevo.2017.00159

Di Maio A, Guarino FM, Affronte M, Caputo V (2003) Reliability of the skeletochronological method in Caretta caretta from the Adriatic Sea. In: Margaritoulis D, Demetropoulos A (Eds) Proceedings of the First Mediterranean Conference on Marine Turtles, Nicosia, 113-115.

Failla G, Calais Junior A, Pavanelli L, Nunes LC (2018) Histomorphometric analysis of gonads of green turtles (Chelonia mydas) stranded on the coast of Espírito Santo state, Brazil. Arquivo Brasileiro de Medicina Veterinária e Zootecnia 70: 213-221. https://doi. org/10.1590/1678-4162-9506

Giacoma C, Balletto E, Bentivegna F, Guarino FM, Hochscheid S, Maio N, Mingozzi T, Piovano S, Scaravelli D (2007) Caretta caretta. In: Corti C, Capula M, Luiselli L, Razzetti E, Sindaco R (Eds) Fauna D’Italia. Reptilia (Vol. XLV). Calderini, Bologna, 201-219.

Goshe LR, Avens L, Scharf FS, Southwood AL (2010) Estimation of age at maturation and growth of Atlantic green turtles (Chelonia mydas) using skeletochronology. Marine Biology 157: 1725-1740. https:// doi.org/10.1007/s00227-010-1446-0

Goshe LR, Snover ML, Hohn AA, Balazs GH (2016) Validation of back-calculated body lengths and timing of growth mark deposition in Hawaiian green sea turtles. Ecology and Evolution 10: 3208-3215. https://doi.org/10.1002/ece3.2108

Guarino FM, Crottini A, Mezzasalma M, Randrianirina EJ, Andreone F (2019) Skeletochronological estimate of age and growth in a large riparian frog from Madagascar (Anura: Mantellidae: Mantidactylus). Herpetozoa 332: 39-44. https://doi.org/10.3897/herpetozoa.32. e35576

Guarino FM, Crovetto F, Mezzasalma M, Salvidio S (2015) Population size, age structure and life expectancy in a Lacerta agilis (Squamata; Lacertidae) population from northwest Italian Alps. North-western Journal of Zoology 11: 241-246.

Guarino FM, de Pous P, Crottini A, Mezzasalma M, Andreone F (2011) Age structure and growth in a population of Pelobates varaldii (Anura, Pelobatidae) from northwestern Morocco. Amphibia-Reptilia 32: 550-556. https://doi.org/10.1163/017353711X605678

Guarino FM, Di Già I, Sindaco R (2008) Age structure in a declining population of Rana temporaria from northern Italy. Acta Zoologica Academiae Scientiarum Hungaricae 54: 99-112.

Guarino FM, Di Maio A, Caputo V (2004) Age estimation by phalangeal skeletochronology of Caretta caretta from Mediterranean Sea. Italian Journal of Zoology 71, Suppl. 2: 175-180. https://doi. org/10.1080/11250000409356630

Guarino FM, Garcia G, Andreone F (2014) Huge but moderately longlived: age structure in Leptodactylus fallax, a critically endangered frog from Montserrat, West Indies. Herpetological Journal 24: 167-173.

Hays CG, Mazaris AD, Schofield G, Laloë JO (2017) Population viability at extreme sex-ratio skews produced by temperature-dependent sex determination. Proceedings of the Royal Society B 284: 20162576. https://doi.org/10.1098/rspb.2016.2576

Klinger RC, Musick JA (1992) Annular growth layers in juvenile loggerhead turtles (Caretta caretta). Bulletin of Marine Science 51: 224-230.

Lenz AJ, Avens L, Campos Trigo C, Borges-Martins M (2016) Skeletochronological estimation of age and growth of loggerhead sea turtle (Caretta caretta) in the western South Atlantic Ocean. Austral Ecology 41: 580-590. https://doi.org/10.1111/aec.12347

Lutcavage ME, Plotkin P, Witherington B, Lutz PL (1997) Human impacts on sea turtle survival. In: Lutz PL, Musick JA (Eds) The Biology of Sea Turtle. CRC Press, Boca Raton, 387-409.

Maffucci F, D’Angelo I, Hochscheid S, Ciampa M, De Martino GD, Travaglini A, Treglia G, Bentivegna F (2013) Sex ratio of juvenile loggerhead turtles in the Mediterranean Sea: is it really $1: 1$ ? Marine Biology 160: 1097-1107. https://doi.org/10.1007/s00227012-2160-x

Margaritoulis D, Argano R, Baran I, Bentivegna F, Bradai MN, Caminas JA, Casale P, De Metrio G, Demetropulos A, Gerosa G, Brendan JG, Haddoud DA, Houghton J, Laurent L, Lazar B (2003) Loggerhead turtles in the Mediterranean Sea: present knowledge and conservation perspectives. In: Bolten AB, Witherington BE (Eds) Loggerhead Sea Turtles, Chap. 11. Smithsonian Books, Washington, 175-198.

Mascarenhas R, Santos R, Zeppelini D (2005) Stranded sea turtles on the coast of Paraíba, Brazil. Marine Turtle Newsletters 107: 13-14.

McNeill JB, Avens L, Hall AG, Goshe LR, Harms CA, Owens DW (2016) Female-bias in a long-term study of a species with tem- 
perature-dependent sex determination monitoring sex ratios for climate change research. PLoS ONE 11(8): e0160911. https://doi. org/10.1371/journal.pone.0160911

Meylan PA, Schuler R, Moler P (2002) Spermatogenic cycle of the Florida softshell turtle, Apalone ferox. Copeia 2002: 779-786. https:// doi.org/10.1643/0045-8511(2002)002[0779:SCOTFS]2.0.CO;2

Mezzasalma M, Andreone F, Aprea G, Glaw F, Odierna G, Guarino FM (2017a) Molecular phylogeny, biogeography and chromosome evolution of Malagasy dwarf geckos of the genus Lygodactylus (Squamata, Gekkonidae). Zoologica Scripta 46: 42-54. https://doi. org/10.1111/zsc.12188

Mezzasalma M, Andreone F, Aprea G, Glaw F, Odierna G, Guarino FM (2017b) When can chromosomes drive speciation? The peculiar case of the Malagasy tomato frogs (genus Dyscophus). Zoologischer Anzeiger 268: 41-46. https://doi.org/10.1016/j.jcz.2017.04.006

Mezzasalma M, Andreone F, Glaw F, Petraccioli A, Odierna G, Guarino FM (2016) A karyological study of three typhlopid species with some inferences on chromosome evolution in blindsnakes (Scolecophidia). Zoologischer Anzeiger 264: 34-40. https://doi. org/10.1016/j.jcz.2016.07.001

Mingozzi T, Masciari G, Paolillo G, Pisani B, Russo M, Massolo A (2007) Discovery of a regular nesting area of loggerhead turtle Caretta caretta in southern Italy: a new perspective for national conservation. Biodiversity and Conservation 16: 3519-3541. https:// doi.org/10.1007/s10531-006-9098-6

Parham JF, Zug GR (1997) Age and growth of loggerhead sea turtles (Caretta caretta) of coastal Georgia: an assessment of skeletochronological age-estimates. Bulletin of Marine Science 61: 287-304.

Perez-Bermudez E, Ruiz-Urquiola A, Lee-Gonzalez I, Petric B, Almaguer-Cuenca N, Sanz-Ochotorena A, Espinosa-Lopez G (2012) Ovarian follicular development in the hawksbill turtle (Cheloniidae: Eretmochelys imbricata L.). Journal of Morphology 273: 13381352. https://doi.org/10.1002/jmor.20062

Petitet R, Secchi ER, Avens L, Kinas PG (2012) Age and growth of loggerhead sea turtles in southern Brazil. Marine Ecology Progress Series 456: 255-268. https://doi.org/10.3354/meps09681

Piovano S, Clusa M, Carreras C, Giacoma C, Pascual M, Cardona L (2011) Different growth rates between loggerhead sea turtles (Caretta caretta) of Mediterranean and Atlantic origin in the Mediterranean Sea. Marine Biology 158: 2577-2587. https://doi.org/10.1007/ s00227-011-1759-7
Rondinini C, Battistoni A, Peronace V, Teofili C (2013) Lista Rossa IUCN dei Vertebrati Italiani. Comitato Italiano IUCN e Ministero dell'Ambiente e della Tutela del Territorio e del Mare, Roma, 56 pp. Simmons DJ (1992) Circadian aspects of bone biology. In: Hall BK (Ed.) Bone: Bone Growth (Vol. 6). CRC Press, Boca Raton, 97-134. Sinsch U (2015) Review: Skeletochronological assessment of demographic life-history traits in amphibians. Herpetological Journal 25: 5-13.

Snover ML, Avens L, Hohn AA (2007) Back-calculating length from skeletal growth marks loggerhead sea turtles Caretta caretta. Endangered species Research 3: 95-104. https://doi.org/10.3354/esr003095

Snover ML, Hohn AA (2004) Validation and interpretation of annual skeletal marks in loggerhead (Caretta caretta) and Kemp's ridley (Lepidochelys kempii) sea turtles. Fishery Bulletin 102: 682-692.

Snover ML, Hohn AA, Goshe LR, Balazs GH (2011) Validation of annual skeletal marks in green sea turtles Chelonia mydas using tetracycline labeling. Aquatic Biology 12: 197-204. https://doi. org/10.3354/ab00337

Tomaszewicz CNT, Seminoff JA, Avens L, Goshe LR., Peckham SH, Rguez-Baron JM, Bickerman K, Kurle CM (2015) Age and residency duration of loggerhead turtles at a North Pacific bycatch hotspot using skeletochronology. Biological Conservation 186: 134-142. https://doi.org/10.1016/j.biocon.2015.03.015

Wallace BP, Di Matteo AD, Hurley BJ, Finkbeiner EM, Bolten AB, Chaloupka MY, Hutchinson BJ, Abreu-Grobois FA, Amorocho D, Bjorndal KA, Bourjea J, Bowen BW, Duenas RB, Casale P, Choudhury BC, Costa A, Dutton PH, Fallabrino A, Girard A, Girondot M, Godfrey MH, Hamann M, Lopez-Mendilaharsu M, Marcovaldi MA, Mortimer JA, Musick JA, Nel R, Pilcher NJ, Seminoff JA, Troeng S, Witherington B, Mast RB (2010) Regional management units for marine turtles: a novel framework for prioritizing conservation and research across multiple scales. PLoS ONE 5: e15465. https://doi. org/10.1371/journal.pone.0015465

Wolke RE, George A (1981) Sea Turtle Necropsy Manual. NOAA Technical Memorandum NMFS-SEFC-24.

Zug GG, Parham JF (1996) Age and growth in leatherback turtles, Dermochelys coriacea (Testudines: Dermochelyidae): a skeletochronological analysis. Chelonian Conservation and Biology 2: 244-249.

Zug GR, Wynn AH, Ruckdeschel C (1986) Age determination of loggerhead sea turtles, Caretta caretta, by incremental growth marks in the skeleton. Smithsonian Institute Contributions to Zoology 427: 1-34. https://doi.org/10.5479/si.00810282.427

\section{Supplementary material 1}

\section{Tables S1-S4}

Authors: Fabio Maria Guarino, Fabio Di Nocera, Francesco Pollaro, Giorgio Galiero, Doriana Iaccarino, Domenico Iovino, Marcello Mezzasalma, Agnese Petraccioli, Gaetano Odierna, Nicola Maio

Data type: species data

Explanation note: Table S1. Nesting activity of Caretta caretta on the Campanian beaches in 2002-2018. Table S2. Mortality data on Caretta caretta used. Table S3. Age and sex and cause of death of Caretta caretta. Table S4. Data on sexual maturity of Caretta caretta based on the gonadal histology of a subset $(n=18)$ of skeletochronological study sample.

Copyright notice: This dataset is made available under the Open Database License (http://opendatacommons.org/licenses/odbl/1.0/). The Open Database License (ODbL) is a license agreement intended to allow users to freely share, modify, and use this Dataset while maintaining this same freedom for others, provided that the original source and author(s) are credited.

Link: https://doi.org/10.3897/herpetozoa.32.e47543.suppl1 